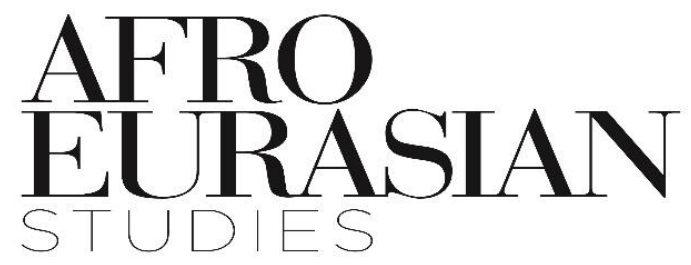

[AFES], 2019, 8 (1): 55-80

\title{
Power and Stability Policies in the Black Sea-Caspian Region in the Context of Max Weber's Authority Approach
}

\begin{tabular}{|c||}
\hline \hline İhsan ÇAPCIOĞLU \\
Prof., Ankara University Faculty of Theology \\
ihsancapcioglu@yahoo.com, \\
Orcid Id: 0000-0003-4796-5232 \\
Ahmed Hamza ALPAY \\
PhD Student, Ankara University Graduate School of Social Sciences \\
Middle East Specialist \\
ahmedhamza0606@outlook.com \\
Orcid Id: $0000-0002-8781-6939$ \\
\hline \hline
\end{tabular}

Article Information

Article Types : Research Article

Received : 24.02 .2019

Accepted : 28.03.2019

Published : 29.03 .2019

Pub Date Season: March 2019

Cite as: ÇAPCIOĞLU, İ, ALPAY, A. (2019). Power and Stability Policies in the Black Sea-Caspian Region in the Context of Max Weber's Authority Approach. Afro Eurasian Studies, 8 (1), 55-80. Retrieved from http://dergipark.gov.tr/afes/issue/44214/531691

Plagiarism: This article has been reviewed by at least two referees and scanned via a plagiarism software.

Copyright (C) Published by MUSIAD- Ataköy 7-8-9-10 Mah. Cobancesme E5 Yanyol Cad. No:4 Bakirkoy, 34158 Istanbul / Turkey Tel +90 (212) 3953302 Fax +90 (212) 3950001 aestudies@musiad.org.tr 


\title{
Power and Stability Policies in the Black Sea-Caspian Region in the Context of Max Weber's Authority Approach
}

\begin{abstract}
Weber defined the authority that gave legitimacy to power based on the concept of sovereignty and tried to understand the level of awareness of the individual's social actions. Together with the phenomenon of power, who played an active role in the strategic platform formed at the same time the hegemony of the authority. The playmakers, who are the active subjects of International Relations, produce proactive-structural policies considering the power balances. In this context, the Black Sea and the Caspian Basin are not only affected by energy, politics and power policies on geopolitical axes but also affect these policies. Turkey is strengthening its central position taking an active role in the Black Sea and the Caspian Basin energy and stability policies for the balance of power in the Eurasian axis. In this study, on the scale of the Black Sea and the Caspian Basin; in terms of Turkey, regional and global actors in energy policies, geopolitics and the balance of power will be examined.
\end{abstract}

Key Words: Power, Authority, Policy, Causality, Hegemony. 


\section{Introduction}

The 18th century, also known as the "Century of Enlightenment" was the century of humanistic philosophies that put the human in the center of the universe. In fact, the Enlightenment was a period in which humanism, the most important of the Renaissance movements of the 14th and 15th centuries, appeared again but on an exceptionally large scale. Putting human beings in the center of the universe brings along giving priority to the subject, but not to the object in philosophy and especially in knowledge theory; and giving priority to the individual, but not to the society as a whole beyond-individual in the life of society. It is obvious that this humanistic perspective will affect the view of history and society (Özlem, 2017, p. 36).

The boundaries of the maps far beyond the known world and away from our eyes are also the place where the first writers, who wrote utopias, deployed their stories. Not many utopias were produced during the medieval period since the perfect society was postponed to the afterlife, millennia or after the redevelopment of Jesus. However, when first the time of Renaissance and then the first periods of modernity were reached, the star of the utopia shone again (Atwood, 2014). More than a statesman or a clergy, Thomas More is a Renaissance reformist as he writes Utopia, and is a Humanist writer with eyes far beyond his era. Utopias have always existed for people who questioned the time they lived and produced ideas. More has set off Plato's flawless state of mind, but in Utopia, it has applied this perfection to all community life. The Utopians considered the natural purpose of all humanitarian efforts to be satisfied with life and said that living in harmony with nature was equivalent to being virtuous (More, 2010).

Compared to utopias, ideologies are an inseparable part of the political experience of the modern world. Ideologies produce various perspectives for understanding and explaining the world (Y1lmaz, 2008, p. 7). The individual who lives in ideology tries to form himself as a free subject who has the right to choose his thoughts (Althusser, 1989, p. 71). At the same time, the individual tries to mold the theories put forward and created in the minds of the superstructure or certain people, which are necessary for a particular structure 
(Gramsci, 2016, p. 58). Ideologies can also be considered as "the regulations of the truth" because they also own a claim that strives to illuminate the truth. As a language of political rhetoric, ideology determines what we think and how we behave, by presenting a set of premises and assumptions about how things work and how they should work in society. As "the regulations of the truth" ideology is always associated with the ruling power (Heywood, 2016, p. 36).

In this study including ideology, state, sovereignty and humanitarian approach as discourse; the concept of authority in Weber's thought is first discussed in various aspects. In this context, the concepts of strategy, political causality, hegemony and political politics are associated with the authority in conceptualization between cases and events. Finally, on the scale of the Black Sea and Caspian Basin, the context of the research topic is handled in the example of energy policies, geopolitics and balance of power in terms of Turkey, regional and global actors.

\section{Max Weber's Authority Typology}

Although Weber began his academic career with legal studies, he soon focused on comparative research of the transformation between Western and Eastern communities. He always faced a dilemma between choosing scientific research or politics as a profession. He finally decided to devote himself to the task of scientific research. His working experiences include power, authority, leadership, bureaucracy, rationality, and organization which form the basis of his statements for complex social phenomena. All of these elements also appear in the interpretation of modern educational systems (Rao \& Singh, 2018, P. 74).

While Weber emphasizes the "necessity of interpreting the meaning of actions according to the actor" to explain the distinguishable regularities in human behavior (Aksan, 2016, p. 429), he states that there is the rationality idea of individual action under the understanding of the modern social organization rationality. According to Weber, the modern social organization rationality has natural boundaries as well as the nature of the individual action. The individual is the one whose behavior is not rational to the extent that his actions are not self-conscious and intentional, is supported by habit, or is driven by the 
emotions. On the other hand, the individual is the one whose behavior is rational to the extent that the individual behaves deliberately and is aware of what he is doing (Weber, 2017, pp. 75-77).

In the beginning, Weber tried to find answers to the question, "Why do people obey?" In his view, ruling power is a factor that allows the orders to be accepted. The concept of Legitimacy is another element that allows this power to be adopted. Weber's concept of authority is formed by the combination of these two concepts (Akçakaya, 2016, pp. 281-282). The power for Weber is the possibility that an actor is in the position of being able to do whatever he wants even if he faces resistance and whatever basis it is based on in a social relationship (Ok, 2017, p. 45; Sancak, 2016, p. 34). In this case, the authority is to have the power, to direct other people by using power to discipline them and to ensure them acting according to a higher standard (Çapcioğlu et al. 2010 , p. $54)$.

According to Weber (2012a), sovereignty is one of the most important elements of social action in its most common meaning. Of course, every form of social action does not contain a structure of sovereignty. But, sovereignty plays an important role in most types of social action even if it is not clear at first sight. The emergence of rational unity from the inappropriate social action in many cases depends on sovereignty and its implementation. If we look at the law as the pretensions given to a person against one or more people and as the authority to issue orders to people who are not given such a right or borrowers, the whole of modern law can be perceived as the distribution of sovereignty to the hands of people who are given legal rights (pp. 307-309). In a rational, positive legal system, the concepts related to the legitimacy of the law are sociologically valid to the extent that it has practical consequences for the behavior of lawmakers, practitioners and social groups concerned with the law. Every natural law has not been revolutionary in its intentions in order to ensure that certain norms are realized with violence or passive disobedience against an existing order. In fact, natural law has also served to legitimize the most diverse types of authoritarian powers (Weber, 2014a, pp. 369-370). 
In Weber's view, three pure forms of legitimate authority come to the forefront. The validity of this legitimacy thesis may be based on the following thoughts in mutual dependence:

- Legal authority: it is based on the legitimacy of normative rules and on the belief that those who are granted the right to give orders according to these laws.

- Traditional Authority: it is based on the sanctity of the traditions that have been perpetuated since ancient times and the legitimacy of those who use power according to these traditions.

- Charismatic Authority: it is based on the sanctity of the exception, its heroism, its exemplary traits or the adherence to the sanctity of the order or the normative patterns that are described or ordered by him (Weber, 2013, p. 54).

The geopolitics of the Black Sea and Caspian Basin associated with authority typology in Weber's view constitute a strategic position in the struggle for power and rulership and in the formation of hegemony area. The countries of both regions have made themselves accepted as important economic forces with the Trans-Anatolian Natural Gas Pipeline Project (TANAP), Baku-TbilisiCeyhan (BTC) oil pipeline, Baku-Tbilisi-Erzurum (BTE) natural gas pipeline projects. The historical and cultural ties of the countries of the region with Turkey require regional cooperation beyond competition. The US-Russia competition, which has recently intensified in world politics, shows itself also with regional alliances. Turkey, under favor of its position as a central country in this process, retains its power with its military and economic potential in the conflicts of energy and political interest of the ruling powers. In recent years, Turkey has taken important risks and responsibilities in regional stability policies, especially in the Middle East, the Black Sea and the Caspian Basin. These risks and responsibilities arise as a geostrategic outcome for Turkey as well as a political and economic gain in terms of regional and cultural geography. In this context, the arguments used by policymakers to give continuity and power to the concept of authority; the relationship between the 
strategies in the global and regional balances, the political causality in the power phenomenon, hegemony, and the political politics that we will try to address with subheadings below are becoming important.

\subsection{Strategy in Global and Regional Power Balances}

The most fundamental function of a state is to sustain its presence and preserve its independence at any cost (Polat, 2015, p. 86). According to modern perceptive, the state is a legally defined concept; in an objective sense, a dominant state force inside and outside; in terms of geography, it strongly points to the territory of the country where the borders are drawn-to the state site-; in social aspects it points to all members of a country (Habermas, 2012, p. 15). The state authority means the ability to declare and enforce the laws of the country -all citizens of this authority, in some way, the rules that must be obeyed by anyone physically there (Bauman, 2009, pp. 180-181).

Brzezinski (2005) describes active strategic players as the states that have the capacity and the national will to exercise power or influence beyond their borders in order to alter - to a degree that affects America's interests-the existing geopolitical state of affairs (p. 64). Physical, economic and technical, cultural and religious, racist and historical, and finally legal and strategic characteristics have been intertwined to make changes in the world (Celerier, 1963, p. 18). According to Weber; the dignity that stems from power means, in practice, the glory and honor of establishing political power over another community. Although it is not always in the form of annexation and domination, it means the expansion of power. The great political communities are the natural supporters of this kind of dignity claims (2014b, p. 259).

\subsection{Political Causality in Power Phenomenon}

Hans J. Morgenthau, who attributed central importance to the phenomenon of power in international politics, emphasizes that it is the concept of interest expressed by this, and it is not possible to establish any national or international policy theory without this concept (Aydemir, 2016, p. 129). This means the use 
of the military forces, vast territories, underground and aboveground natural resources, the crowded population, the power originating from the developed economy and the established political management system held by the country which has the hard power (Anaz, 2013, p. 11).

The concept of global domination power itself is a relatively new historical development. People have lived in isolated communities for millennia, unaware of the existence of their distant neighbors. Immigration and occasional conflicts with foreigners occurred in an environment where the rest of the world was not even aware of it (Brzezinski, 2012a, p. 16). According to Brzezinski (2012b), the problems of classical power and geopolitics are ongoing. The global political awakening and the transformation of humanity in its subjective state has become a global situation, which began with the French Revolution and spreads from Europe to Asia in the late 19th and early 20th centuries (p. 269).

According to Barnett, most of the Pentagon strategists, who say that the real struggle began with the end of the cold war, advocate the protection of the United States' position as the world's only super-military force, not the use of it (Macit, 2006, p. 143). As the failure of the United States to impose its intention in Iraq has become clear, the real goals of the occupation have been no longer hidden behind the ornamental language (Chomsky, 2017, p. 65). The war in Iraq was related to the basis of the "national security" and the future power of the United States. The role America played as the sole dominant power was the unnamed cause of the war. It was about power and above all, geopolitical power (Engdahl, 2008). During the Anglo-American invasion of Iraq and in the subsequent anarchic environment; the heritage of the country was largely destroyed, the National Museum was plundered, the libraries which had the manuscripts of the Qur'an were set fire to, and the ancient Sumerian cities were destroyed. Similar ones are now happening in Syria (Fisk et al., 2015, p. 262).

\subsection{Hegemony}

According to Weber (2014c), sovereignty never limits itself intentionally to merely calling for material, emotional or national motives to ensure its continuity. In addition, it also tries to create and develop a belief about its own 
'legality' (p.322). 322). As seen in all political communities that have followed each other in history, the state is based on a relationship that manifests itself in the form of human's hegemony on the human. It has the authority based on a legal situation and rules that are established in a rational manner; this compliance fulfills the obligations which are convenient to the established system. This is the ruling power employed by the modern state official, like all the representatives of the ruling power who approach the power in this point of view (Weber, 2006, pp. 28-29).

The idea that discourses cannot be considered independent of those who express themselves and who are exposed to these discourses has become very popular especially in Europe thanks to international relations theorists influenced by post-modern thinkers such as Michel Foucault. According to this perceptive, political discourses and analysis and even modern international relations theories can never be unbiased. Critical theorists aim to examine and reveal the unobtrusive dimensions of the power construction that cannot be seen with behavioral and materialist perspectives by problematizing the power relations underlying the discourses (Kadercan, 2014, p. 331). Based on the paradigm of "discourse of power" or "discourse based on power", the approach to which there is an organic link between power and thought systems inevitably leads us to the discussion of whether knowledge is transformed into power. The outcome of this discussion willy-nilly shows how the reality of power for social meaning was developed and presented through discourse/language channel. (Büyükakınc1, 2014, p. 84).

Hegemony is achieved through the whole of organisms that act through nongovernmental or cultural communication and are generally called a special (Femia, 2015, p. 59). Since 1945, American hegemony, or more precisely, American domination, has stood on two pillars. The first is that the US Dollar is in the position of global reserve money through Wall Street. The second is the irresistible military power role played by the Pentagon (Engdahl, 2011, p. 5 ). Though we do not want to return to a world where great powers clash, we need to be aware of the need for power. There is one thing states can do, that is 
to gather and assemble the legitimate power in a meaningful way (Fukuyama, 2012, p. 160).

\subsection{Political Politics}

Saying that the existence of a power in society is necessary and inevitable, Ibn Khaldun explains that a minority compared to the ones ruled in the community is in the jurisdiction of the people and is authorized in the works of all peoples (Göze, 2016, pp.104-105). First of all, it is necessary to determine what the best form of living is to be able to thoroughly examine what the best form of government is (Aristo, 1970, p. 150). There is a natural law that regulates the natural state and everyone has to obey; this law called the mind teaches everyone who consulted him that they should not harm the life and health of others, and should not take away their freedom or property because people are equal and independent (Rosen \& Wolff, 2006, pp. 34-35).

According to Nietzsche, the approval of the idea of the Hegelian historical world process meant that any form of ruling power was accepted without question, whether represented by the government, public, or the absolute majority in society (Emden, 2013, p. 156). It has now become impossible to distinguish between political and social ones any more. Because they are linked to each other by the indicator called economy since the French Revolution. The autonomy of politics is inversely proportional to the hegemony of society. Liberal thought has always lived with a dialectical longing between the two (Baudrillard, 2010, pp. 22-24).

The universal experience in which violence breeds violence, where social or economic power interests can be combined with idealistic reforms or even revolutionary movements, and where violence against a particular injustice is not the ultimate result of greater justice, but of greater power or the victory of reason has not been hidden from intellectuals who do not have political interests (Weber, 2012b, p. 364). The emphasis on the necessity to encounter the realities of the modern world without illusions is a constant theme in Weber's political writings. Whoever wants to make politics on earth, above all, has to be free 
from illusions. The theme itself is also integrated with the concept of Weber's world ethical irrationality (Giddens, 1992, p. 49).

People who express their thoughts in words that they do not dominate, who put those thoughts into verbal forms of which their historical dimensions escape from the grasps, believe that their words submit to them, and do not know that they are subject to their wishes (Foucault, 2013, p.417). The mindset is the beliefs and attitudes that almost all the people of an era share indisputably and without understanding what it is. When the political actor is under pressure, his typical reactions become exaggerated. Although the essence of his behavior is based on a part of the truth, his behavioral pattern may be due to warping of the truth (Robins, 2001).

\section{The Geopolitics of the Black Sea and Caspian Basin on the Turkish} Axis

If an organization with a ruling power permanently secures its existence and order within a certain geographical area through the physical violence and threat imposed by the administrative body, it is called the political organization (Weber, 2012c, p. 103). According to nationalist thought, to have control over a particular soil is to draw the boundaries of that geography and to dominate the historiography of those soils. Nationalization of the geography is to create a "national field" that is glorified materially and morally (Durgun, 2012, p. 17).

Geopolitics is a discipline that examines the life and activity areas of countries, nature, geographic position with the resources it covers in the formation of state power, the shaping of force balances in international relations (Özdağ, 2003, p. 9) and the humanity in relation to the spatial factor (Dugin, 2015 ). Because of its geopolitical position and importance, Eurasia has become the source or outlet of major global struggles and conflicts in recent years. In the modern era, Eurasia was divided according to the East-West discrimination that revealed a form of limitation that we are closely acquainted with today and the principle of the center-periphery relationship. Although these distinctions have lost their 
grip on Euro-Asia relations today, they are still influential in the political orientations and are guiding the identity policies (Rumford, 2015, p. 251).

The Black Sea is a semi-enclosed sea with $432,000 \mathrm{~km} 2$ area and 4340 kilometers long coastline. It is an important and strategic sea, which has a unique position with two narrow exits to the open seas through an inland sea. According to the "Rimland Theory" developed by Spykman, the Black Sea connects Europe to the Middle East and Asia. According to Mahan's "Sea Power Theory ", the power dominating the Black Sea will have a geographical position to control the region (Kurt, 2015, p. 405).

If we consider the Black Sea Basin as a whole today, we can say that it has a different meaning for each state that has regional interests (Aktaş \& Güntay, 2014, p. 164). Among the reasons of the interest focused in the Black Sea are the change in the threat perception of the USA after 9/11 (New York) and 3/11 (Madrid) terrorist attacks and the broad Black Sea project of the United States. Its influence to the riparian countries as well as the Balkans, the Caucasus, the Caspian, Central Asia, and perhaps a part of Iran, the back door to the Great Middle East, its location as a strategic corridor between the Atlantic region and the problematic Middle East that represents the 65 percent of the world oil reserves, and the smuggling route of radical terrorist organizations and organized crime networks increases the geopolitical importance of the Black Sea. If we look from the viewpoint of the Russian Federation, energy card, the Turkey initiative, the close environmental doctrine, the use of frozen conflicts such as Karabakh, South Ossetia, Abkhazia, and Transnistria are effective (TEPAV, 2007, pp. 8-10). 
Map 1: The Black Sea and the Caspian Basin

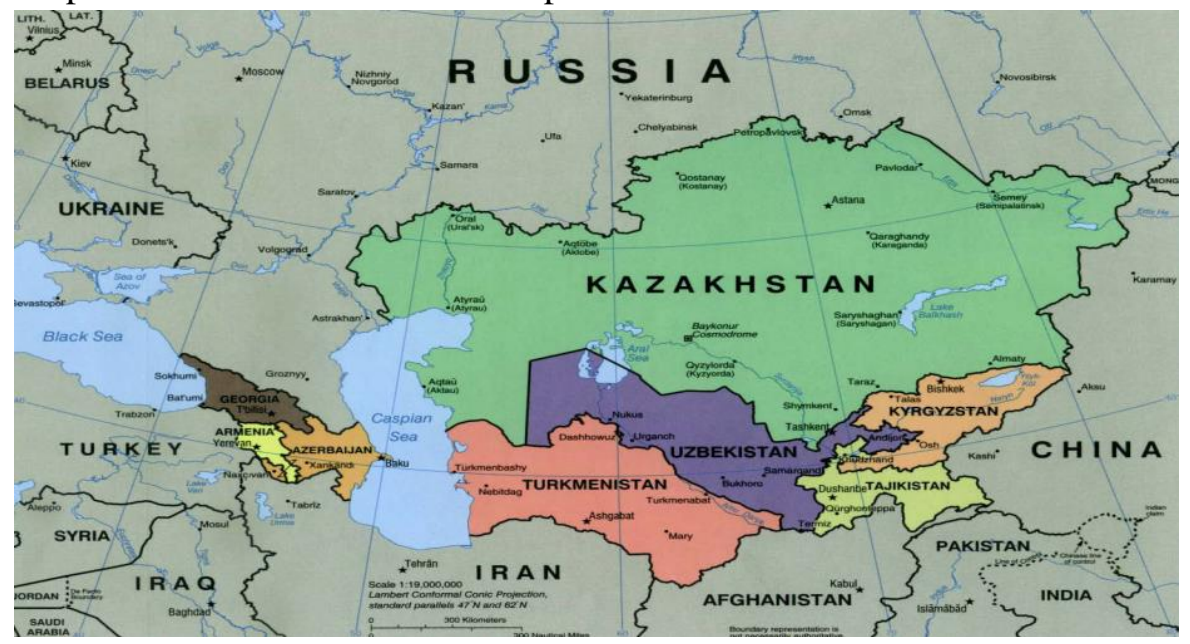

Source: (researchbriefings.files.parliament.uk)

The Caspian Sea, covering an area of approximately $371,000 \mathrm{~km} 2$ with a length of 1204 kilometers is almost Japan-sized area. The average depth of the Caspian is $184 \mathrm{~m}$ and the largest depth ratio is $1025 \mathrm{~m}$ (Yolcu, 2014, p. 13). The uncertainty of the legal status of the Caspian in the new geopolitical order, formed by the collapse of the Soviet Union (USSR) and the emergence of new coastal states in the Caspian region, has been one of the important issues of discussion. After they have won their independence; Kazakhstan, Azerbaijan and Turkmenistan have gained the right in the region as the new coastal states, which have been trying to build their national identities on the one hand and their development on the other hand. These new circumstances caused a problem concerning historical share in the Caspian, based on previous agreements between Russia and Iran. The Caspian Sea, which has been a political and economic interest between Russia and Iran for more than two centuries, has become the interest of five states after this stage (Kinik \& Güntay, 2016, P. 255). In the 5th Summit of Heads of the Caspian Littoral States held in Aktau, Kazakhstan, the parties signed the agreement determining the legal status of the Caspian. In the Treaty (1) each party in the Caspian Sea will 
have territorial waters up to a limit not exceeding 15 nautical miles and establish a 10 nautical miles-wide fishery zone adjacent to the territorial waters (2) except for the Caspian Littoral States, there will be no military force in the region, and (3) all problems related to the Caspian Sea will be solved peacefully (Anadolu Agency, 12.08.2018).

\section{Map 2: Trans Anatolian Natural Gas Pipeline Project, TANAP}

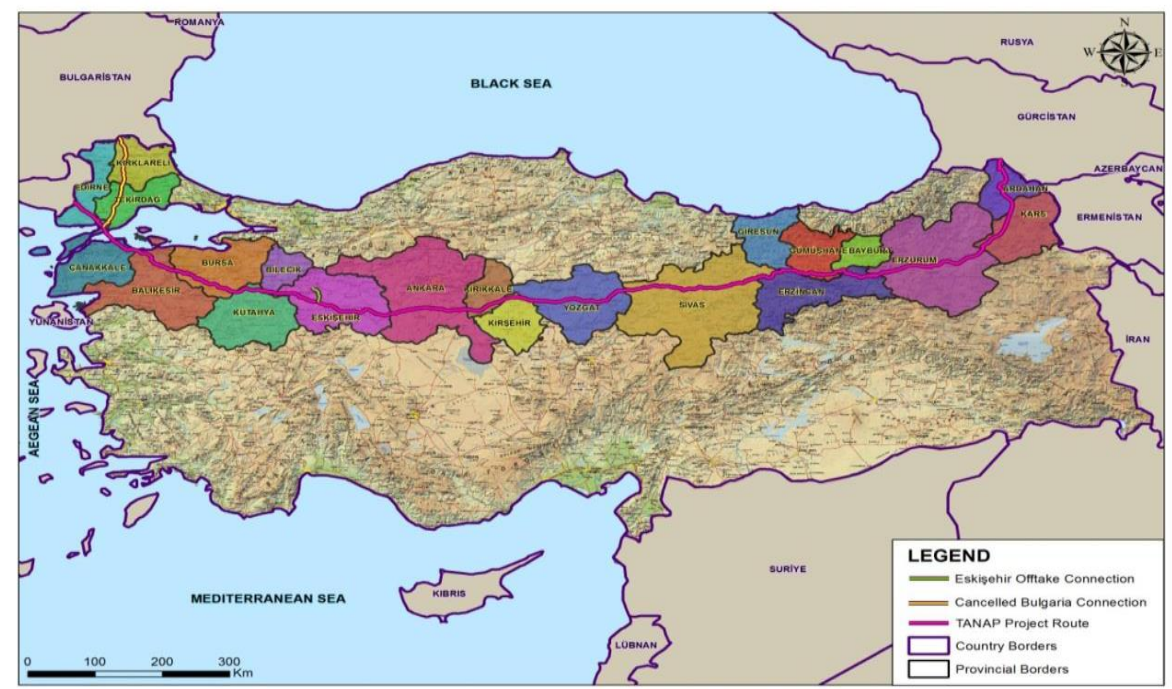

Source: (www.miga.org)

Energy is a must for all countries and has a feature that affects the economy completely. Energy infrastructures such as energy resources, transmission lines and power plants are the most critical elements of developed or developing countries because they have a feature that affects and changes the outcome of all other critical infrastructures (Caşın et al., 2015, p. 4). Azerbaijan's presence on the Caspian Sea with its oil, gas wealth; Georgia's presence on the Black Sea coast and the transportation of energy resources are of strategic importance (Gafarl1, 2015, p. 63). Azerbaijan defined part of the Caspian Sea as the national territory in its constitution and, on the basis of this, started to grant oil/gas exploration/development licenses within the region defined in 1994 (Sevim, 
2015, p. 102). The wealth of Caspian is transferred to the world via the BakuTbilisi-Ceyhan (BTC) oil pipeline and the Baku-Tbilisi-Erzurum (BTE) natural gas pipeline (Sarıahmetoğlu, 2014, p. 15; Karagöl et al, 2016, p. 7). The TransAnatolian Natural Gas Pipeline Project (TANAP), which was put on the agenda after NABUCCO had been involved in history, was considered as the most pragmatic and realistic project among alternative options by the governments of Turkey and Azerbaijan (Erdoğan, 2017, p.15). The natural gas produced with the help of TANAP in the natural gas field of Azerbaijan's Shah Sea 2 in the Caspian Sea and other sites south of the Caspian Sea will be transported primarily to Turkey and then to Europe. The inauguration ceremony of TANAP, which was held in Eskişehir with the participation of President Recep Tayyip Erdoğan, was attended by the heads of state and government, energy ministers, managers of energy companies and senior bureaucrats (NTV, 12.06.2018).

The geographical location of a country and its strategic resources within its borders is an important place within the geopolitical elements of that country. Turkey is the main contact point of the world power centers, the US and Russia. Turkey, which has a significant position in the bilateral struggle between these two states, is on the junction or separation point of Europe and the Middle East (Harunoğulları, 2016, p. 403). Turkey has a unique position; through the straits, it can control the sea routes reaching to the Mediterranean and the Middle East from Caspian Littoral states, the Central European and Baltic states that are connected to the Black Sea by canals and rivers. Turkey has also a geographic location that can affect the Aegean Sea, the Central and Eastern Mediterranean (Şener, 2015, p. 339). Istanbul and Çanakkale straits are among the most important marine routes in the world along with the Suez Canal in petroleum transportation (Ayhan, 2009, p. 164). The Black Sea and Caspian Basin countries, who want to market rich oil and natural gas resources to international markets in order to accelerate their economic development, cooperated with regional actors such as Turkey and developed oil and natural gas pipeline projects to transport hydrocarbon reserves in the region to international markets (Köten, 2013, pp. 77). 


\section{The Assessment and the Conclusion}

Weber defines power as an element that allows the acceptance and implementation of orders given on the basis of legitimacy. In Weber's view, it is observed that the domain of power constitutes a dynamic process in establishing and maintaining political authority. Sovereignty, as a constructive element of social action, provides an elbow room for lawmakers and practitioners in the formation of positive rational law. Sovereignty; in order to ensure its continuity, it creates a belief together with the behavioral psychologies of social groups; it affects social phenomena and events sociologically.

States are making friendly/ foes identification on geopolitical and geostrategic axis. The aim of the states is to maintain their existence while preserving their legal and political independence. Political discourse and analysis constitute a sphere of influence in the rational use of legitimate power by the states - with the effect of knowledge on power. Policymakers who provide political efficiency -in discourse/language practice- maintain individual and social dialectical.

Geographical location - energy sources, climate, population density, continental shelf - is the most decisive factor in the creation of a national and economic space on the geopolitical axis, which is the reality within itself. Especially given the advantages of energy resources in providing economic superiority, regional and global cooperation as well as threat perceptions are emerging. Global and regional forces are using military and economic power, with the influence of political discourses -while realizing their earning policies. Political politics provide mobility to actors in critical decision-making processes.

The Black Sea is a geopolitical and geostrategic sea. It has a very critical geographical location that provides opportunities for the opening to the Balkans, the Caspian, the Caucasus, the Middle East and the Mediterranean. The Black Sea is an important energy corridor where the Russian Federation, the Caucasus 
and the Caspian oil and natural gas are delivered to the world markets. It is a potential source of energy with its hydrocarbon deposits. This position of the Black Sea in terms of energy increasingly increases the geopolitical and economic competition on a global scale. It also adds a new dimension to EuroAtlantic security. Considering the historical relations of the Black Sea Littoral States, the international organizations they are in and the international organizations they want to become a member of; it is observed that there are differences between geopolitical goals. This situation complicates the establishment of a permanent and stable security environment in the Black Sea. Even the non-regional actors have begun to intervene in the security dynamics of the Black Sea. NATO, the EU and the United States carefully monitor the development and dissemination of The Russian Federation's effectiveness in Central Asia, the Caucasus and the Black Sea. In particular, the 2008 Georgia and 2014 Ukraine crises adversely affected the relations between Western countries and neighboring countries. The issues related to the Ukraine Crisis, Transnistria, Abkhazia and South Ossetia remain their actualities and continue to affect developments. The Black Sea, due to its geopolitical position, directly influences the security dynamics of the Balkans, the Caspian and the Caucasus (Çomak, 2017).

Among the countries bordering the Black Sea, Turkey is the chief country that develops a unique discourse in the Black Sea region, carries out policies for the region continuously, and attaches importance to this geography in its geopolitics. Turkey has tried to pursue an active policy against the developments in the Black Sea since the 1990s. The Black Sea Economic Cooperation (BSEC), launched by Turkey's initiative, is the first indicator of an active effort on this issue when it is not yet clear in what direction the international system will be developed in the Black Sea geography. As stated in the Black Sea Charter, the Black Sea states have taken steps to establish BSEC, a regional cooperation model based on human rights and fundamental freedoms, aiming to achieve prosperity through economic freedom, social justice, equal security and stability, open to communication with other countries, regional initiatives, international organizations and financial institutions by sharing their views on regional cooperation, which is the part of the process of EU 
integration. In addition, Turkey's unchanging policy towards the straits in its geopolitics makes Turkey one of the leading countries whose discourse is the most prominent in the region (Erbaş, 2012, pp. 138-143).

Turkey has a cultural common point with countries such as Turkmenistan, Uzbekistan, Kazakhstan, Kyrgyzstan and Azerbaijan, where the so-called Central Asian states historical ties are strong and the Muslim population is the majority. From this point of view, it can be said that Turkey has geopolitical power, necessary cultural and political tools and strategic importance to mediate the realization of leadership aspirations in the region in the world system shaped after the Cold War. Turkey is also considered a key country in the transition of the EU to Eurasia and the economic and political stability of the region. This increases Turkey's importance in energy projects and highlights Turkey's influence in the formation of international partnerships. The main importance of TANAP in this process is that it is the route to transport Caspian and Middle Eastern resources to Europe rather than the amount of natural gas it will carry in the first stage. TANAP, which is the basis of the Southern Gas Corridor, is planned to operate with 16 billion $\mathrm{m} 3$ of natural gas annually, 6 billion $\mathrm{m} 3$ of gas is sold in the domestic market of Turkey and 10 billion $\mathrm{m} 3$ of gas is sent to European markets. The capacity planned to be 16 billion $\mathrm{m} 3$ per year in 2020 is expected to reach 23 billion $\mathrm{m} 3$ in 2023 and 31 billion $\mathrm{m} 3$ in 2026. TANAP is a project in which Turkmenistan, Iran, Iraq, Israel and other countries of the region are willing to move natural gas resources to Europe alongside Azerbaijan gas and negotiations are ongoing with the countries which are parties in this framework. With the implementation of these projects, Turkey aims to become a North-South energy corridor with the East-West Energy Corridor in the near future, thus becoming the key country to save EU countries from the energy problem (Furuncu, 2018, pp. 555-557).

The Black Sea and Caspian Basin geopolitics associated with the concept of authority in Weber's view constitute a strategic position in the struggle for power and rulership and in the formation of hegemony area. In recent years, Turkey has taken important risks and responsibilities in regional stability policies, especially in the Middle East, the Black Sea and the Caspian Basin. These risks and responsibilities arise as a geostrategic outcome for Turkey as 
well as a political and economic gain in terms of regional and cultural geography. In this context, the world geography is increasingly in need of the sovereignty of economic, religious, cultural, military-stability in regional and global terms. The evolution of regional war policies into the policies of peace and stability is very important for the survival and development of humanitarian law. The realization of this process will be possible if all states establish sovereign areas in accordance with legitimate and international law. 


\section{REFERENCES}

Akçakaya, M. (2016). Weber'in Bürokrasi Kuramının Bugünü ve Geleceği. Gazi Üniversitesi Sosyal Bilimler Dergisi, Özel Say1, 275-295.

Aksan, G. (2016). Max Weber ve Değerler Sosyolojisi: Bir Metodolojik İkilemin Düşündürdükleri. Selçuk Üniversitesi Edebiyat Fakültesi Dergisi, (35), 427-446. DOI Number: http://dx.doi.org/10.21497/sefad.35126

Aktaş, H. \& Güntay, V. (2014). Karadeniz ve Hazar Havzasında Alternatif Güvenlik Anlayışı ve Arayışları, Mikro Örgütlenme Biçimi. Hazar'dan Karadeniz'e Stratejik Bakış. Yeşilot, Okan, İstanbul: Yeditepe Yayınevi, 163173.

Althusser, L. (1989). İdeoloji ve Devletin İdeolojik Aygitlart. Alp, Yusuf Özışık, Mahmut (trans.), İstanbul: Birikim Yayınları.

Anadolu Ajans1. (12.08.2018). 5 ülke Hazar Denizi'nin hukuki statüsü konusunda anlaşt1. https://www.aa.com.tr/tr/dunya/5-ulke-hazar-denizininhukuki-statusu-konusunda-anlasti/1228982, (Access.Date: 14.01.2019).

Anaz, N. (2013). ABD Örnekleminde Yumuşak Güç Kavramı ve Dış Politika. Ankara Siyasal ve Ekonomik Araştırmalar Merkezi (ASEM) Rapor.

Aristo (1970). Politika. (Trans. Niyazi Berkes), Ankara: MEB.

Atwood, M. (2014). Başka Dünyalar: Bilimkurgu ve Hayal Gücü. (Trans. Selin Siral), 1st Edition, İstanbul: Kolektif Kitap.

Aydemir, E. (2016). Dış Politikada Yumuşak Gü̧̧ ve Medya. 1st Edition, İstanbul: Kalkedon Yayınları.

Ayhan, V. (2009). Avrupa'nın Enerji Arz Güvenliğinde Türkiye: Petrol, Doğal Gaz ve Entegrasyon. Uluslararası İlişkiler, 5 (20), 155-178.

Baudrillard, J. (2010). Sessiz Yığınların Gölgesinde: Toplumsalın Sonu. (Trans. Oğuz Adanır), 4th Edition, Ankara: Doğu Batı Yayınları. 
Bauman, Z. (2009). Sosyolojik Düşünmek. Yılmaz, Abdullah (trans.), 6thEdition, İstanbul: Ayrıntı Yayınları.

Brzezinski, Z. (2005). Büyük Satranç Tahtast: Amerikanın Küresel Üstünlüğü ve Bunun Jeostratejik Gereklilikleri. (Trans. Yelda Türedi), İstanbul: İnk1lâp Kitabevi.

Brzezinski, Z. (2012a). Stratejik Vizyon: Amerika ve Küresel Güç Buhranı. (Trans. Sezen Yalçın \& Abdullah Taha Orhan), 1st Edition, İstanbul: Timaş Yayınları.

Brzezinski, Z. (2012b). Amerika ve Dünya: Amerikan Dış Politikasının Geleceğine Dair Konuşmalar. (Trans. Manolya Aşı), 2 .Edition, İstanbul: Profil Yayıncilik.

Büyükakıncı, E. (2014). Postmodern Okumalar ve James Der Derian: Güvenlik, Diplomasi ve Savaş. Postmodern Uluslararası İlişkiler Teorileri-2. (Comp.. Tayyar Arı), 1st Edition, Bursa: Dora Basım Yayın, 77-103.

Caşın, M.H., Nifti, E., \& Gücüyener, A. (2015). Kritik Enerji Altyapı Güvenliği El Kitabl. Hazar Strateji Enstitüsü.

Celerier, P. (1963). Jeopolitik ve Jeostrateji. (Trans. Emin Gezen), Gnkur. Basımevi, Ankara: Araştırma ve Geliştirme Başkanlığı Yayınları No: 26.

Chomsky, N. (2017). Güç Kimin Elinde?. (Trans. Cihan Özpınar), İstanbul: İnk1lâp Kitabevi.

Çapcıŏglu, İ., Şahin, M. C., \& Erdoğruca, N. (2010). Max Weber Sosyolojisinde Karizmatik Otorite ve Dini Liderlik. Türkiye Sosyal Araştırmalar Dergisi, Y11: 14, (2), 51-76.

Çomak, H. (2017). Karadeniz Jeopolitiği. (Ed. Hasret Çomak, Volkan Caner, Tatar Sancaktar \& Burak Şakir Şeker), 1st Edition, İstanbul: Beta Basım Yayım Dağıtım. 
Dugin, A. (2015). Rus Jeopolitiği: Avrasyacı Yaklaşım. (Trans. Vügar İmanov), 8th Edition, İstanbul: Küre Yayınları.

Durgun, S. (2012). Yer Bilgisinden Ulusal Coğrafya'ya. Mekân, Kimlik, Güç ve Dış Politika. (Comp.. S. Gülden Ayman), 1st Edition, İstanbul: Yalın Yayınc1lik, 13-38.

Emden, C. J. (2013). Modern Siyasal Düşünce ve Friedrich Nietzsche. (Trans. Gamze Varım), 1st Edition, İstanbul: Türkiye İş Bankası Kültür Yayınları.

Engdahl, W. (2008). Petrol, Para, İktidar: Anglo-Amerikan Petrol Politikasl ve Yeni Dünya Düzeni. (Trans. Ertuğrul Bilal), 1st Edition, İstanbul: Alfa Yayınları.

Engdahl, W. (2011). Wall Street ve Amerikan Yüzyılının Çöküşü. (Trans. Özgün Şulekoğlu \& İlkay Ata), 1st Edition, İstanbul: Bilim+Gönül Yayınları.

Erbaş, G. (2012). Klasikten Eleştirel Jeopolitiğe Karadeniz Jeopolitĭginin Dönüşümü. (Yayımlanmamış Doktora Tezi), Ankara Üniversitesi, Sosyal Bilimler Enstitüsü, Ankara.

Erdoğan, N. (2017). TANAP Projesinin Türkiye ve Azerbaycan Enerji Politikalarındaki Yeri ve Önemi. Ömer Halisdemir Üniversitesi İktisadi ve İdari Bilimler Fakültesi Dergisi, 10 (3), 10-26. DOI: 10.25287/ohuiibf.319259

Femia, J. (2015). Gramsci, Machiavelli ve Uluslararası İlişkiler. Uluslararası İlişkiler ve Siyasal Düşünce. (Comp.. Faruk Yalvaç), 1st Edition, İstanbul: Röle Akademik Yayıncılık, 57-67.

Fisk, R., Cockburn, P., \& Sengupta, K. (2015). Suriye Cehenneme Düşüş 2011 2014: Çağdaş Haberciliğin Unutulmaz Antolojisi. (Trans. Aslı Adalıer, Senem Transik \& Buğra Yasin), İstanbul: İyidüşün Yayınları.

Foucault, M. (2013). Kelimeler ve Şeyler: Insan Bilimlerinin Bir Arkeolojisi. (Trans. Mehmet Ali Kılıçbay), 4th Edition, Ankara: İmge Kitabevi Yayınları. 
Fukuyama, F. (2012). Devlet İnşası: Yirmi Birinci Yüzyılda Yönetişim ve Dünya Düzeni. (Trans. Türkan Çolak), 1st Edition, İstanbul: Profil Yayıncılık.

Furuncu, Y. (2018). TANAP'ın Orta Asya ve Avrupa Enerji Pazarlarına Etkisi. Yönetim ve Ekonomi: Celal Bayar Üniversitesi İktisadi ve İdari Bilimler Fakültesi Dergisi, 25 (2), 543-561.

Gafarl1, O. (2015). Avrasya Çıkmazı: Yeni Büyük Oyunu Kim Kazanacak?. 1st Edition, Ankara: Nobel Akademik Yayıncılık.

Giddens, A. (1992). Max Weber Düşüncesinde Siyaset ve Sosyoloji. (Trans. Ahmet Çiğdem), 1st Edition, Ankara: Vadi Yayınları.

Göze, A. (2016). Siyasal Düşünceler ve Yönetimler. 16th Edition, İstanbul: Beta Basım Yayım.

Gramsci, A. (2016). Hapishane Defterleri. (Trans. Aycan Özüpek), Ankara: Yason Yayınları.

Habermas, J. (2012). “Öteki Olmak”, “Öteki’’yle Yaşamak: Siyaset Kuramı Yazlları. (Trans. İlknur Aka), 6th Edition, İstanbul: Yapı Kredi Yayınları.

Harunoğulları, M. (2016). Jeopolitik Rekabet Alanı: Hazar Havzası ve Türkiye. TÜCAUM Uluslararası Coğrafya Sempozyumu, 13-14 Ekim 2016, Ankara, 401-413.

Heywood, A. (2016). Siyasi İdeolojiler: Bir Giriş. (Trans. Levent Köker), 10th Edition, Ankara: BB101 Yayınları.

http://researchbriefings.files.parliament.uk/documents/RP05-24/RP05-24.pdf, (E.T: 17.01.2019).

http://www.miga.org/sites/default/files/archive/Documents/SPGDisclosures/T ANAP\%20Executive \%20Summary \%20of\%20ESIA \%20and\%20Supporting\% 20Environmental\%20and\%20Social\%20Safeguards.pdf, (E.T: 17.01.2019). 
Kadercan, B. (2014). Güç. Uluslararası İlişkilere Giriş: Tarih, Teori, Kavram ve Konular. (Ed. Şaban Kardaş \& Ali Balc1), 1st Edition, İstanbul: Küre Yayınlar1, 323-335.

Karagöl, E. T., Kızılkaya, M., \& Kaya, S. (2016). Statü Sorunu İkileminde Hazar'da Enerji Denklemi. SETA Analiz, Sayı: 155, 1-32nd

Kınık, H., \& Güntay, V. (2016). Siber Güvenlik Temelinde Kritik Altyapılar ve Hazar Havzası. Uluslararası Sosyal Araştırmalar Dergisi, 9 (47), 252-259.

Köten, F. (2013). Boru Hattı Projelerinin Hazar Havzası Jeopolitik ve Jeoekonomisindeki Rolü. Avrasya İncelemeleri Dergisi (AVID), II/1, 65-84.

Kurt, S. (2015). NATO ve AB'nin Karadeniz Bölgesine Yönelik Politikaları. International Journal of Social Science, Number: 31, Winter II, 403-419. Doi number: http://dx.doi.org/10.9761/JASSS2626

Macit, N. (2006). Küresel Güç Politikalarl, Türkiye ve İslam. 1stEdition, Ankara: Fark Yayınları.

More, T. (2010). Ütopya. (Trans. Ayfer G. Cambier), 2nd Edition, İstanbul: Dergâh Yayınları.

NTV Haber (12.06.2018). Trans Anadolu Doğalgaz Boru Hattı (TANAP) Açıldı. https://www.ntv.com.tr/ekonomi/trans-anadolu-dogalgaz-boru-hatti tanapacildi,oWdT1oKaxEC ZCsPI C6Uw, (E.T: 14.01.2019).

Ok, A. Ş. (2017). Max Weber'de Otorite ve Meşruiyet Tipolojisi. Avrasya Sosyal ve Ekonomi Araştırmaları Dergisi, 4 (8), 42-54.

Özdağ, M. (2003). Türkiye ve Türk Dünyası Jeopolitiği. 1stEdition, Ankara: Avrasya-Bir Vakfı Yayınları.

Özlem, D. (2017). Max Weber'de Bilim ve Sosyoloji. 1st Edition, İstanbul: Notos Kitap Yayınevi. 
Polat, S. (2015). Türkiye Iç̧in Jeopolitik Rota. 2nd Edition, İstanbul: Kaynak Yayınları.

Robins, R. S. (2001). Politik Paranoya: Nefretin Psikopolitiği. (Trans. İnci Kurmuş), 1st Edition, İstanbul: Doğan Kitapçı1ık.

Rosen, M., \& Wolff, J. (2006). Siyasal Düşünce. (Trans. Sevda Çalışkan \& Hamit Çalışkan), 1st Edition, Ankara: Dost Kitabevi Yayınları.

Rumford, C. (2015). Sinırlar ve Yeniden Sinırlandırma. Doğu ve Batı'nın Ötesinde Asya ve Avrupa. (Ed. Gerard Delanty), (Trans. Firdevs Bulut), 1st Edition, İstanbul: Matbu Kitap, 251-266.

Sancak, K. (2016). Uluslararası Illişkilerde Güç Kavramı ve Yumuşak Güç. 1st Edition, Ankara: Nobel Akademik Yayıncılık.

Sarıahmetoğlu, N. (2014). Hazar'ın Stratejik Önemi ve Bölgesel Güvenlik Tehditleri. Hazar'dan Karadeniz'e Stratejik Bakış. (Comp.. Okan Yeşilot), İstanbul: Yeditepe Yayınevi, 7-60.

Sevim, C. (2015). Küresel Enerji Stratejileri ve Jeopolitik. 3rd Edition, Ankara: Seçkin Yayınc1lı.

Srinivasa Rao, S., \& Singh, S. (2018). Max Weber's Contribution to the Sociology of Education: A Critical Appreciation. Contemporary Education Dialogue, 15(1), 73-92. DOI: 10.1177/0973184917744964

Şener, B. (2015). Tarihsel Boyutlarıyla Boğazlar'ın Jeopolitik Ve Jeostratejik Önemi. International Journal of Social Science, Number: 35, Summer I, 327349.

TEPAV (2007). Karadeniz'in Değisşen Jeopolitiği ve Alternatif Arayışlar. Türkiye Ekonomi Politikaları Araştırma Vakfi (TEPAV), 1-30.

Weber, M. (2006). Meslek Olarak Siyaset. (Trans. Afşar Timuçin \& Mehmet Sert), 1st Edition, İstanbul: Chiviyazıları Yayınevi. 
Weber, M. (2012a). Ekonomi ve Toplum. (Trans. Latif Boyac1), Cilt 2, 1st Edition, İstanbul: Yarın Yayınları.

Weber, M. (2012b). Din Sosyolojisi. (Trans. Latif Boyac1), 1st Edition, İstanbul: Yarın Yayınları.

Weber, M. (2012c). Sosyolojinin Temel Kavramları. (Trans. Medeni Beyaztaş), 3rd Edition, İstanbul: Yarın Yayınları.

Weber, M. (2013). Bürokrasi ve Otorite. (Trans. H. Bahadır Akın), 6th Edition, Ankara: Adres Yayınları.

Weber, M. (2014a). Hukuk Sosyolojisi. (Trans. Latif Boyac1), 1st Edition, İstanbul: Yarın Yayınları.

Weber, M. (2014b). Sosyoloji Yazılart. (Trans. Taha Parla), 14th Edition, İstanbul: Deniz Yayınları.

Weber, M. (2014c). Toplumsal ve Ekonomik Örgütlenme Kuramı. (Trans. Özer Ozankaya), 2nd Edition, İstanbul: Cem Yayınevi.

Weber, M. (2017). Rasyonalitenin Sinirlart: Max Weber'in Sosyal ve Ahlaki Düsüncesi Üzerine Bir Deneme. (Trans. Baysar Tanıyan \& Güney Çeğin), Ankara: Phoenix Yayınevi.

Yılmaz, S. (2008). Güç ve Politika. 1st Edition, İstanbul: Alfa Yayınları.

Yolcu, T. (2014). Hazar Bölgesinin Hukuki Statüsü Sorunu ve Türkiye'nin Bölgeye Yönelik Siyaseti. ASSAM Uluslararası Hakemli Dergi, 1 (2), 11-30. 